J. comp. Physiol. 79, 259—280 (1972)

(C) by Springer-Verlag 1972

\title{
The Effect of Activity on Oxygen Consumption, Oxygen Debt, and Heart Rate in the Lizards Varanus gouldii and Sauromalus hispidus
}

\author{
Albert F. Bennett \\ Department of Zoology, University of Michigan, Ann Arbor, Michigan 48104
}

Received May 12, 1972

Summary. Oxygen consumption and heart rate were measured during rest and activity in the lizards Varanus gouldii and Sauromalus hispidus. Oxygen debt was calculated from postactive oxygen consumption. Standard metabolic rates of the two animals are similar but Varanus consumes much more oxygen during activity than does Sauromalus (Fig. 1-3). The latter has a constant active metabolic rate above $30^{\circ} \mathrm{C}$ and accumulates a large oxygen debt, which is repayed slowly (Fig. 4). Varanus recovers rapidly from activity (Fig. 5), presumably because of the smaller lactacid debt incurred. Heart rate increment in Sauromalus is high (Fig. 8). This variable cannot be responsible for the limitation of active oxygen consumption; calculations of oxygen pulse suggest that an inability to increase A-V difference and/or stroke volume are implicated (Fig. 9). Varanus have evolved mechanisms to sustain high levels of oxygen consumption superior to those of other reptiles investigated. The role of anaerobiosis in the biology of both animals is discussed.

\section{Introduction}

A considerable amount of data has been gathered on resting metabolic rate in reptiles, and this is summarized and discussed extensively elsewhere (Dawson, 1967; Templeton, 1970; Bennett and Dawson, 1971). The effects of controlled activity have been investigated in only a few species of large reptiles (Amphibolurus, Bartholomew and Tucker, 1963; Iguana, Moberly, 1968a, b; Pituophis, Greenwald, 1971; Sphenodon, Wilson and Lee, 1970; Tiliqua, Bartholomew et al., 1965; Varanus, Bartholomew and Tucker, 1964). In most of these species, aerobic scope, the augmentation of oxygen consumption above resting levels during maximal activity (see Fry, 1947), is low and decreases with increasing body temperature $\left(T_{b}\right)$ over the normal temperature range of activity. Varanus, however, is reported to have exceptional powers of oxygen utilization during activity (Bartholomew and Tucker, 1964). This study was undertaken to investigate oxygen transport and its functional bases in Varanus gouldii, the racehorse goanna, and an iguanid lizard of comparable size and thermal preferendum, Sauromalus hispidus, the spiny chuckwalla. This paper examines the capacities of the two species 
to function aerobically during activity, and the contribution of heart rate to oxygen transport is also analyzed.

The monotypic family Varanidae (Varanus) is widespread throughout the Old World. All of its members are similar in body form and habits, differing chiefly in body size. Varanus are all carnivorous, preying principally on rodents and lizards. They maintain large territories, foraging over great distances, and are active and extremely wary animals, difficult to approach and capture. They normally flee at high speeds but will fight savagely if cornered (Cowles, 1930; Mertens, 1942; Bartholomew and Tucker, 1964; Pianka, 1970). Bartholomew and Tucker (1964), in an examination of several Australian species, reported that standard levels of metabolism were twice as high as those of other lizards at normal $T_{b}$ 's, that $T_{b}$ increased during activity, and that oxygen consumption during activity increased with increasing $T_{b}$. Subsequent speculation (Tucker, 1967; Greenwald, 1971) suggested that varanids possess aerobic capacities superior to those of other reptiles.

Varanus possess a morphological specialization suggestive of unusual capacities for aerobiosis. The lung structure has been examined extensively and is far more complex than that of other reptiles, possibly similar to that of primitive mammals or birds (Milani, 1893; Wolf, 1933; Mertens, 1942; Kirschfeld, 1970). Most saurian lungs are relatively simple sacs and have no intrapulmonary bronchi. The respiratory area is confined to the anterior portion of the lung and not developed extensively; the posterior portion is devoid of air cells. The entire organ is not considered efficient in its ability to extract oxygen from rentilated air (Wolf, 1933). Varanus, however, possess cartilage-lined intrapulmonary bronchi and extensive spongy, alveolar-like air cells throughout the lung. Wolf believed that oxygen exchange could be as efficient as that in avian lungs. Although Mertens (1942) maintained that the muscular ridge subdividing the ventricle in Varanus is better developed. than in other lizards, other studies (Mathur, 1944; Copland, 1953) show no cardiovascular specializations that could be interpreted as facilitating oxygen transport or partitioning oxygenated from deoxygenated blood.

The family Iguanidae, with the relatively closely allied forms, the agamids and chameleons, forms one of the largest assemblages of lizards. They are probably not greatly morphologically different from the ancestors of the order Squamata (Romer, 1956). Iguana iguana, the only large representative of the family examined during activity, undergoes considerable lactate production and exhausts easily (Moberly, 1968a). Another large iguanid was chosen for examination to determine whether Iguana is highly specialized metabolically or is representative of the group in its reliance on anaerobiosis. Sauromalus hispidus is a large, herbivorous animal, similar in appearance to its congener, S. obesus 
(Norris and Dawson, 1964). The thermal preferendum of Sauromalus hispidus is $37.1^{\circ} \mathrm{C}$ (K. Nagy, pers. comm.), of S. obesus, $37.9^{\circ} \mathrm{C}$ (Brattstrom, 1965). The active $T_{b}$ of Varanus gouldii is reported as $37.1^{\circ} \mathrm{C}$ (Licht et al., 1966) and $38.1^{\circ} \mathrm{C}$ (Pianka, 1970). Bartholomew and Tucker (1964) reported a mean $T_{b}$ of $35.5^{\circ} \mathrm{C}$ for several species of Varanus, including $V$.gouldii. Both Sauromalus and Varanus, therefore, have activity temperatures of approximately $37-38^{\circ} \mathrm{C}$.

\section{Material and Methods}

\section{Collection and Animal Maintenance}

Fifteen adult Sauromalus hispidus (mean weight: $574 \mathrm{gm}$; range: 396-1061 gm) were collected on Isla Mejia, Baja California Norte, Mexico, and transported to The University of Michigan where all experiments were performed. They were maintained in wood and metal-screen pens equipped with incandescent lights and heat lamps set on a seven hour per day thermal period (1000-1700 EST). They were fed lettuce, dog food, and a weekly supplement of raw egg and vitamin mixture. Water was available at all times. All metabolic measurements were made between January and $A$ pril.

Ten specimens of Varanus gouldii gouldii and V.g. rosenbergi $(674 \mathrm{gm}$, $139-1280 \mathrm{gm}$ ) were collected from widely scattered sites in Western Australia. The lizards were housed in large, open-air pens at the University of Western Australia, where all metabolic measurements were made. The pens were equipped with heat lamps set on a seven hour per day cycle (0900-1600). The animals were exposed to ambient photoperiods. They remained healthy on a diet of live mice and rats and raw kangaroo meat. Water was always available. Experiments were run during January and February.

\section{Measurements of Metabolism and Heart Rate}

To measure metabolic rate during activity, it is necessary to monitor oxygen consumption continuously with little lag time or dilution of expired air. Such measurements are impossible in large metabolic chambers. Therefore, metabolic masks of small volume $(100,175$, and $400 \mathrm{cc})$, which covered the entire head and neck, were fashioned from rubber "wet suit" material and fastened securely to the pectoral region of the animals with contact cement. The masks, which contained incurrent and excurrent air ports, admitted no light, were free from air leaks, and did not interfere with normal ventilation. A mask was generally left on an individual for three days, during which time three metabolic measurements at different $T_{b}$ 's were made. No ill effects were observed after the mask was removed.

The animals were fasted for at least two days before the experiments. Preliminary measurements indicated a substantially lower metabolic rate at night (see also Roberts, 1968). Since minimal values were desired, all experimental determinations were made after 2000 local time. Masked animals were fitted with a rectal thermocouple and gold-plated safety pin leads in front and hind limbs for measurement of $T_{b}$ and heart rate, respectively. The animal was tied to a restraining board and placed in a constant temperature cabinet (regulated at $\pm 0.5^{\circ} \mathrm{C}$ ) before 1200 local time. The temperature of the cabinet was set between $15^{\circ}$ and $42^{\circ} \mathrm{C}$. Dry air was metered through the mask at $150-1000 \mathrm{cc} / \mathrm{min}$. Body and ambient temperatures were monitored with thermocouples connected to a Brown Class 15 recording potentiometer. Heart rate was measured with a Sanborn EKG pre- 
amplifier and recording oscillograph, Model 150 (Sauromalus) or a Grass A.C. preamplifier, Model P5B, and Sanborn 299 D.C. amplifier recorder (Varanus). Oxygen consumption was determined by monitoring the excurrent air line with a Beckman paramagnetic oxygen analyzer, Model G-2 (Sauromalus) or F-3 (Varanus), connected to a Brown Class 15 recording potentiometer. Carbon dioxide and water vapor were removed before oxygen analysis by Ascarite (sodium hydrate asbestos) and Drierite (anhydrous calcium sulfate), respectively. All gas volumes were corrected to standard conditions of temperature and pressure.

During the experimental period, oxygen consumption was monitored for one hour and heart rate was measured every fifteen minutes during that period. All observations were averaged to obtain standard values. To obtain maximum oxygen consumption, the temperature cabinet was opened and gold-plated safety pin electrodes were implanted in the hind limbs of the animal. It was first stimulated by general handling of the limbs and tail, which caused violent struggling. Sometimes a series of electric shocks (2-10 volts, 10 per sec) were delivered with a Grass stimulator, Model S4C for Sauromalus or Model S6C for Varanus, if the animal became refractory to further handling. The animal was stimulated for seven minutes. Oxygen consumption and $T_{b}$ were monitored continuously; heart rate was measured at the end of the stimulation period. Oxygen consumption increased to a peak value during stimulation, maintained that level for 30 to 60 seconds, and slowly declined to resting levels. The return of oxygen consumption to resting levels was monitored for one hour after stimulation. The animals rarely, if ever, moved or struggled if left undisturbed during this recovery period. Occasionally an animal was restimulated during the recovery; it nearly always returned to the maximal level measured previously.

To determine whether the metabolic mask altered standard metabolism, the metabolic rate and heart rate of unmasked, unrestrained Sauromalus were determined. Animals were placed in large metal boxes before 1200 EST and left undisturbed until after 2000 EST. Oxygen consumption, heart rate, and $T_{b}$ were measured as outlined above.

\section{Statistics}

All linear and polynomial equations calculated for this study are the best computed least squares fit to the data. If a function was not obviously linear after transformation, polynomial regressions of increasingly higher degree were computed until no further significant improvement $(p<0.05)$ was obtained. In practice, this never required more than a second-order regression. Standard errors are reported with mean estimates; $95 \%$ confidence limits are used to estimate significance.

\section{Results \\ Oxygen Consumption and Scope}

Metabolic rates are reported in cc oxygen consumed per gm body weight per hour. The results of all oxygen consumption experiments on Sauromalus are given in Fig. 1. No significant difference $(p=0.68$ by analysis of covariance) was found between the metabolic rate of undisturbed animals in metabolic chambers and masked lizards tied to restraining boards. The data on resting animals were pooled and yielded. the regression

$$
\log \mathrm{SMR}=-2.540+0.0396 T_{b}
$$




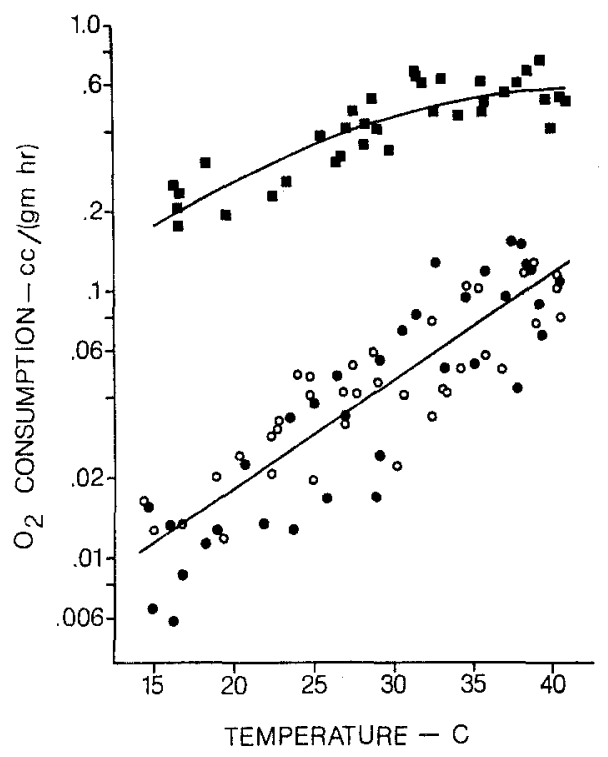

Fig. 1. Standard and active oxygen consumption in Sauromalus hispidus. Shaded circles represent resting animals with metabolic masks; unshaded circles, resting animals without masks; squares, active animals with masks

$Q_{10}$ of the standard metabolic rate is 2.50 . Oxygen consumption of active Sauromalus increased with increasing $T_{b}$ up to approximately $30^{\circ} \mathrm{C}$ and remained constant between $30^{\circ}$ and $41^{\circ} \mathrm{C}$. Analyzed separately, the data at $T_{b}$ greater than $30^{\circ} \mathrm{C}$ have no significant temperature trend. The second degree polynomial which best describes this relationship is $\log$ AMR $=-1.456+0.0566 T_{b}-0.000654 T_{b}^{2} \quad\left(15^{\circ} \mathrm{C} \leqq T_{b} \leqq 40^{\circ} \mathrm{C}\right)$.

$Q_{10}$ values of this function decrease continuously from 2.17 at $15-20^{\circ} \mathrm{C}$ to 1.08 at $35-40^{\circ} \mathrm{C}$. The animals often exhausted during the activity period and ceased to respond to further stimulation.

The results of metabolic experiments on Varanus are reported in Fig. 2. The temperature dependence of standard metabolism decreased continuously from $15^{\circ}$ to $40^{\circ} \mathrm{C}$ such that standard metabolic rate was essentially independent of $T_{b}$ between $30^{\circ}$ and $40^{\circ} \mathrm{C}$. Two animals began hyperventilating at $40.4^{\circ} \mathrm{C}$, although a third animal did not at $40.6^{\circ} \mathrm{C}$. All individuals measured at $42^{\circ} \mathrm{C}$ or above actively hyperventilated. The thermoregulatory increase in ventilation rate resulted in a one- to three-fold increase in metabolic rate, and data on hyperventilating animals are consequently excluded from calculations of standard metabolic conditions. The best least squares description of the resting data is 


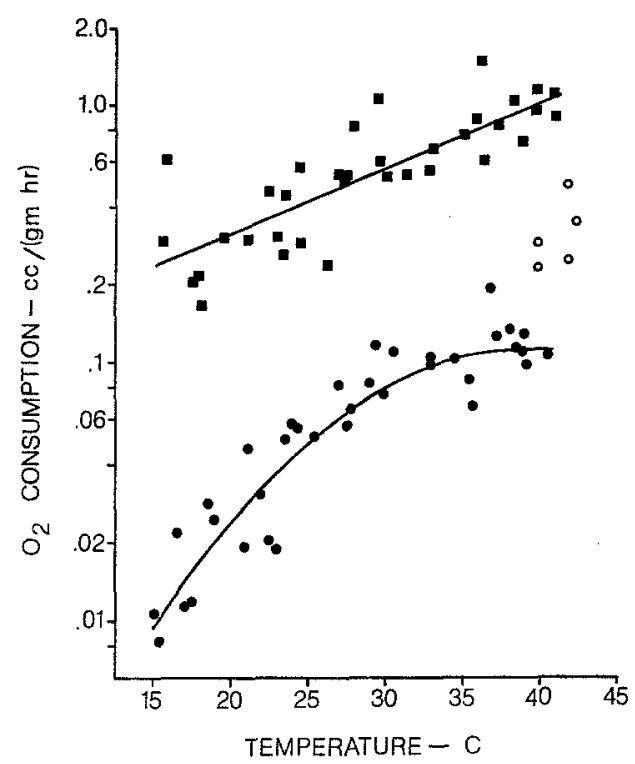

Fig. 2. Standard and active oxygen consumption in Varanus gouldii. Shaded circles represent resting animals; unshaded circles, hyperventilating animals; squares, active animals

$\log \mathrm{SMR}=-3.832+0.150 T_{b}-0.00195 T_{b}^{2} \quad\left(15^{\circ} \mathrm{C} \leqq T_{b} \leqq 40^{\circ} \mathrm{C}\right)$.

$Q_{10}$ decreases from 6.61 at $15-20^{\circ} \mathrm{C}$ to 1.07 at $35-40^{\circ} \mathrm{C}$. Oxygen consumption of active Varanus increased with increasing $T_{b}$ with a constant $Q_{10}$ of 1.78 :

$$
\log \mathrm{AMR}=-0.996+0.0250 T_{b} .
$$

Exhaustion was never observed during stimulation.

The aerobic metabolic scope of both species as a function of $T_{b}$ is given in Fig. 3. Scope values were calculated from regression equations (Eqs. (1) and (2), Sauromalus; Eqs. (3) and (4), Varanus) and not determined directly from measurements of resting and active metabolism on an individual because of changes in $T_{b}$ during activity. The metabolic increment is similar in both animals below $30^{\circ} \mathrm{C}$; however, at $40^{\circ} \mathrm{C}$, the aerobic scope of Varanus is double that of Sauromalus.

Body temperature increased slightly during activity in Sauromalus (mean change: $+0.4^{\circ} \mathrm{C} \pm 0.1$ ). The maximum increase observed was $1.5^{\circ} \mathrm{C}$. Increase in $T_{b}$ was not correlated with ambient temperature. Varanus did not change $T_{b}$ significantly during activity (mean change: $+0.2^{\circ} \mathrm{C} \pm 0.2$ ). The maximum increase observed was $1.3^{\circ} \mathrm{C}$. 


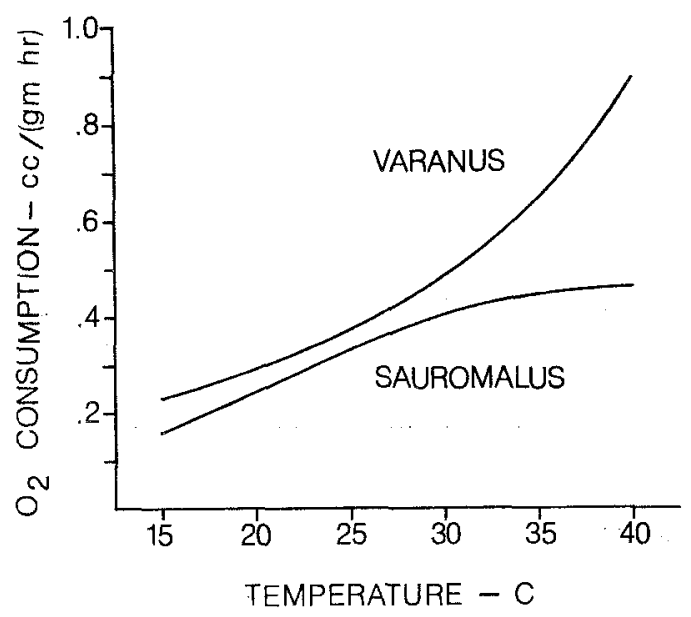

Fig. 3. Metabolic scope in Sauromalus hispidus and Varanus gouldii

\section{Recovery}

In order to determine how rapidly the animals recover standard metabolic levels after exercise, the oxygen consumption of each animal was measured after maximum oxygen consumption until $90 \%$ recovery had been reached. A smooth curve was fitted by eye to the recording of oxygen consumption, and the number of minutes required to reach 25 , $40,50,60,70,75,80$, and $90 \%$ recovery of standard levels was measured. For each of these recovery percentages, a polynomial regression was computed for the time required to reach that percentage recovery as a function of $T_{b}$. These regressions were used to calculate recovery time at $5^{\circ} \mathrm{C}$ intervals between $15^{\circ}$ and $40^{\circ} \mathrm{C}$ for each recovery percentage. The resulting relationships between percentage recovery, time, and $T_{b}$ are given in Figs. 4 and 5 for Sauromalus and Varanus, respectively.

In the range of $T_{b}$ between $20^{\circ}$ and $40^{\circ} \mathrm{C}$, Sauromalus recovers most rapidly from a bout of activity at $25-30^{\circ} \mathrm{C}$ : recovery is slower at $40^{\circ} \mathrm{C}$ than at $20^{\circ} \mathrm{C}$ (Fig. 4). In contrast, the rate of recovery of Varanus continues to increase with increasing $T_{b}$ and is most rapid at $40^{\circ} \mathrm{C}$ (Fig. 5). Sauromalus recovers slightly more rapidly than Varanus, at least in the initial phases of the process, between $15^{\circ}$ and $30^{\circ} \mathrm{C}$, but more slowly at $35^{\circ}$ and $40^{\circ} \mathrm{C}$, temperatures which are closer to the activity range of the animals. At $40^{\circ} \mathrm{C}$, Varanus recovers more than three times as rapidly as Sauromalus. These calculations in terms of percentage recovery obscure the even greater difference in recovery rates between the two animals in terms of decrease in the rate of oxygen consumption, since metabolic scope is higher in Varanus. 


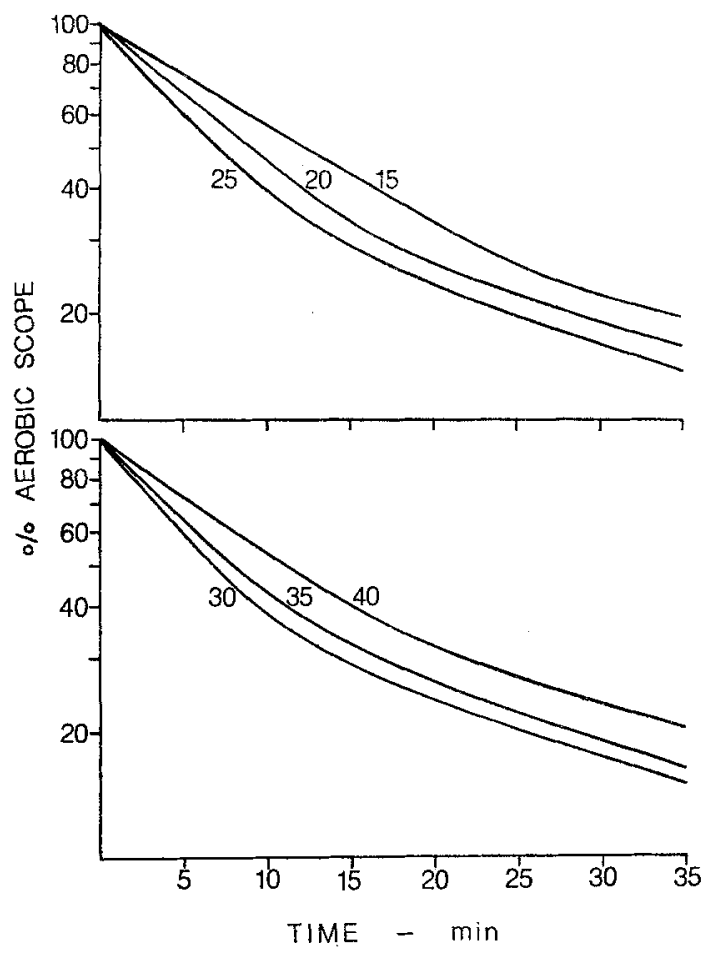

Fig. 4. The effect of body temperature on recovery of standard levels of metabolism after maximal oxygen consumption in Sauromalus hispidus. Body temperature $\left({ }^{\circ} \mathrm{C}\right)$ is given beside each regression

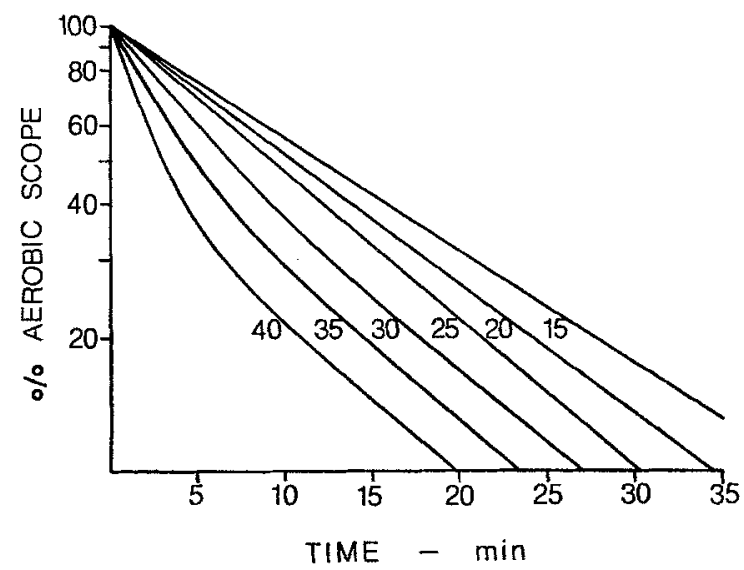

Fig. 5. The effect of body temperature on recovery of standard levels of metabolism after maximal oxygen consumption in Varanus gouldii. Body temperature $\left({ }^{\circ} \mathrm{C}\right)$ is given beside each regression 
If the logarithm of an equilibration rate is plotted as a function of time, a linear relationship between the variables indicates that a single process is operating during the equilibration. Systematic deviations from linearity may indicate that two or more processes are operating with different equilibration rates. The latter is the case when the logarithm of the percentage of recovery is plotted as a function of time for both lizards, as is apparent in Figs. 4 and 5. For Sauromalus at all $T_{b}$ 's and for Varanus at $30^{\circ}-40^{\circ} \mathrm{C}$, the recovery function may be separated into fast and slow eomponents, and the contribution of each to the total increment may be estimated according to the relation:

$$
\% \text { aerobic scope }=K_{1} e^{-\frac{1}{T_{1}} t}+K_{2} e^{-\frac{1}{T_{2}} t}
$$

where $T_{1}$ and $T_{2}$ are the time constants (time in minutes to $63 \%$ recovery) of the fast and slow components, $K_{1}$ and $K_{2}$ are the intercepts of the fast and slow components, $e$ is the base of the natural logarithms, and $t$ is the time in minutes (see Atkins, 1969, for the method of estimation).

Real physiological analogues have been attributed to these fast and slow mathematical components, designated as the alactacid and lactacid debts respectively (Henry, 1951; Henry and De Moor, 1956; Karpovich, 1959). The former consists of the rapid resynthesis of creatine phosphate and reoxygenation of the respratory pigments and the latter represents the catabolism of lactate built up during activity. The total amount of oxygen consumed to repay each of these "debts" may be estimated by integrating the product of the aerobic scope and the intercept of the component over three time constants (to $95 \%$ recovery) for each $T_{b}$. Time constants, intercepts, and oxygen debts are reported in Tables 1 and 2 for Sauromalus and Varanus, respectively. The contribution of the fast (alactacid) component is nearly constant in Sauromalus at all $T_{b}$ 's. The alactacid debt in Varanus cannot be analyzed by this procedure at $15^{\circ}-25^{\circ} \mathrm{C}$ but is strongly temperature dependent between $30^{\circ}$ and $40^{\circ} \mathrm{C}$. Lactacid debt is highly temperature dependent in Sauromalus, much less so in Varanus. The total oxygen debt is much higher in Sauromalus than in Varanus over the range of active $T_{b}$ 's, a consequence of its low aerobic scope.

\section{Heart Rate and Heart Rate Increment}

Heart rates are reported in beats per minute. Heart rates during rest and activity for Sauromalus are given in Fig. 6. No difference $(p=0.96$ by analysis of covariance) was found between resting animals in chambers and resting masked animals. The data were, therefore, pooled to produce the equation for stand heart rate:

$$
\log \mathrm{SHR}=0.0059+0.0473 T_{b} .
$$


Table 1. Oxygen debt acquired during activity by Sauromalus hispidus. See text for explanation and method of calculation

\begin{tabular}{|c|c|c|c|c|c|c|}
\hline & \multicolumn{6}{|c|}{ Body temperature (C) } \\
\hline & 15 & 20 & 25 & 30 & 35 & 40 \\
\hline \multicolumn{7}{|l|}{ Alactacid debt } \\
\hline $\begin{array}{l}T_{1}(\min ) \\
K_{1}(\% \text { scope }) \\
\left.\text { Oxygen debt (cc } \mathrm{O}_{2} / \mathrm{kg}\right)\end{array}$ & $\begin{array}{l}8.3 \\
64 \\
14.5\end{array}$ & $\begin{array}{l}6.0 \\
63 \\
15.0\end{array}$ & $\begin{array}{l}5.0 \\
61 \\
16.5\end{array}$ & $\begin{array}{l}3.8 \\
56 \\
14.2\end{array}$ & $\begin{array}{l}3.8 \\
45 \\
12.8\end{array}$ & $\begin{array}{l}5.7 \\
46 \\
19.8\end{array}$ \\
\hline \multicolumn{7}{|l|}{ Lactacid debt } \\
\hline $\begin{array}{l}T_{2}(\min ) \\
K_{2}(\% \text { scope }) \\
\text { Oxygen debt }\left(\text { co } \mathrm{O}_{2} / \mathrm{kg}\right)\end{array}$ & $\begin{array}{l}57.3 \\
36 \\
55.8 \\
\end{array}$ & $\begin{array}{l}46.2 \\
37 \\
66.3 \\
\end{array}$ & $\begin{array}{l}37.6 \\
39 \\
76.5 \\
\end{array}$ & $\begin{array}{l}30.2 \\
44 \\
87.6\end{array}$ & $\begin{array}{r}26.0 \\
55 \\
105 \\
\end{array}$ & $\begin{array}{c}33.1 \\
54 \\
134 \\
\end{array}$ \\
\hline $\begin{array}{l}\text { Total oxygen debt } \\
\quad\left(\text { ce } \mathrm{O}_{2} / \mathrm{kg}\right)\end{array}$ & 70.3 & 81.3 & 93.0 & 102 & 118 & 154 \\
\hline
\end{tabular}

Table 2. Oxygen debt acquired during activity by Varanus gouldii. See text for explanation and method of calculation

\begin{tabular}{lcccccc}
\hline & \multicolumn{7}{c}{ Body temperature (C) } \\
\cline { 2 - 7 } & 15 & 20 & 25 & 30 & 35 & 40 \\
\hline Alactacid debt & & & & & & \\
$T_{1}$ (min) & - & - & - & 4.1 & 3.2 & 2.1 \\
$K_{1}$ (\% scope) & - & - & - & 23 & 39 & 52 \\
Oxygen debt (cc $\left.\mathrm{O}_{2} / \mathrm{kg}\right)$ & - & - & - & 7.5 & 13.2 & 15.8 \\
\hline Lactacid debt & & & & & & \\
$T_{2}(\min )$ & 16.9 & 14.9 & 13.9 & 12.9 & 12.7 & 12.6 \\
$K_{2}(\%$ scope) & 100 & 100 & 100 & 77 & 61 & 48 \\
Oxygen debt (cc $\left.\mathrm{O}_{2} / \mathrm{kg}\right)$ & 62.6 & 72.2 & 78.5 & 80.4 & 83.5 & 86.6 \\
\hline Total oxygen debt & 62.6 & 72.2 & 78.5 & 87.9 & 96.7 & 102 \\
(cc $\left.\mathrm{O}_{2} / \mathrm{kg}\right)$ & & & & & & \\
\hline
\end{tabular}

$Q_{10}$ for this relationship is 2.74 . The regression for heart rate of active Sauromalus is

$$
\log \mathrm{AHR}=0.740+0.0361 T_{b} .
$$

$Q_{10}$ for this regression is 2.30 .

Heart rates of resting and active Varanus are given in Fig. 7. Hyperventilating animals are excluded from both regressions; they are, however, 


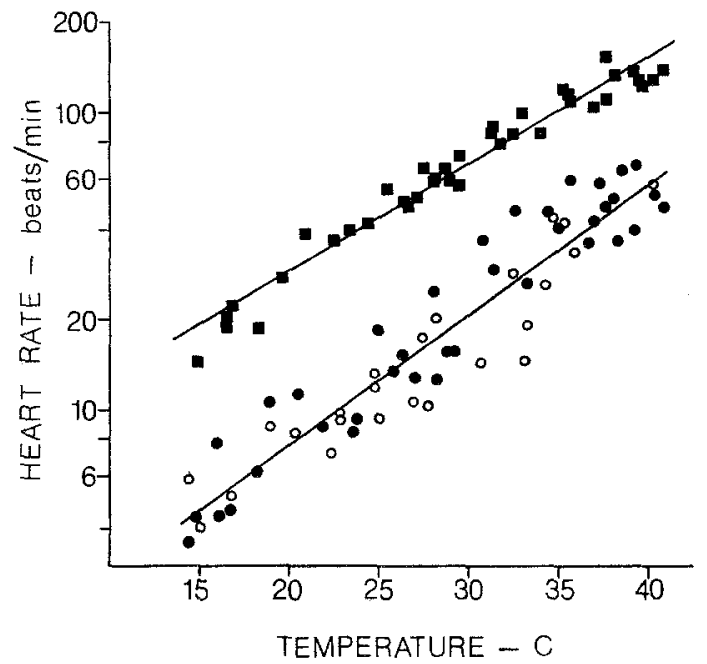

Fig. 6. Standard and active heart rate in Sauromalus hispidus. Symbols are explained in Fig. 1

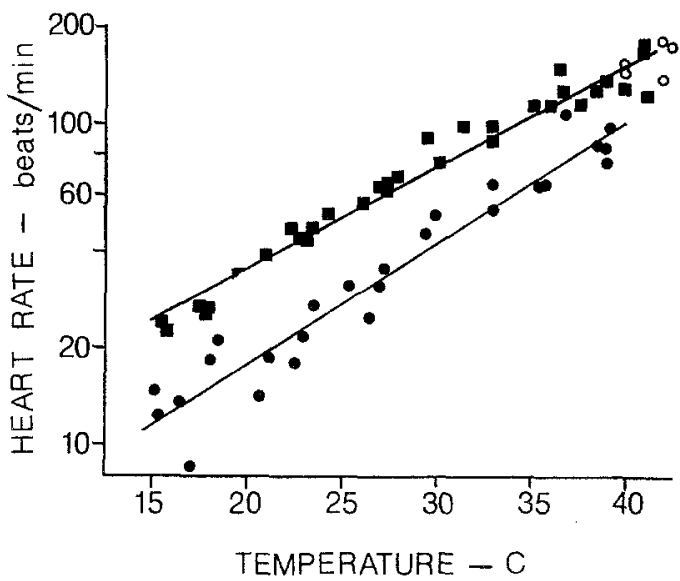

Fig. 7. Standard and active heart rate in Varanus gouldii. Symbols are explained in Fig. 2

indistinguishable from the rates of active animals. The equation deseribing standard heart rate is

$$
\log \mathrm{SHR}=0.499+0.0373 T_{b} .
$$

$Q_{10}$ is 2.36. For active heart rate the regression equation is

$$
\log \mathrm{AHR}=0.908+0.0317 T_{b} .
$$

The corresponding $Q_{10}$ is 2.08 . 


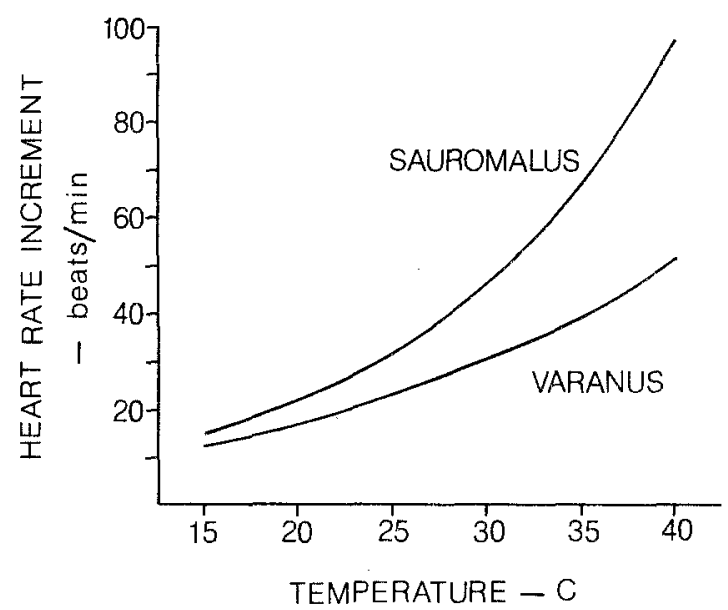

Fig. 8. Heart rate increment during activity in Sauromalus hispidus and Varanus gouldii

Values for heart rate increment, the difference between active and standard heart rates, are shown for both lizards in Fig. 8. The increments are calculated from regression equations (Eqs. (6) and (7), Sauromalus; Eqs. (8) and (9), Varanus). The functions for both animals increase with increasing $T_{b}$. The heart rates of both species when active are almost identical, but the lower standard heart rate of Sauromalus produces a far greater increment. At $37.5^{\circ} \mathrm{C}$, Sauromalus nearly triples its heart rate during activity; heart rate in Varanus increases only by half.

\section{Oxygen Pulse}

Division of the metabolic rate by the heart rate yields the oxygen pulse, the amount of oxygen transported per heart beat. The values for resting and active oxygen pulse for both lizards are reported in Fig. 9. These functions are calculated from Eqs. (1), (2), (6), and (7) for Sauromalus and Eqs. (3), (4), (8), and (9) for Varanus. Standard oxygen pulse is similar in both animals. Active oxygen pulse in Sauromalus declines precipitously above $30^{\circ} \mathrm{C}$ and is only double resting pulse at $40^{\circ} \mathrm{C}$. In Varanus, active oxygen pulse remains high, nearly six times the resting pulse.

The percentage contribution of the increase in heart rate observed during activity to the total increment in oxygen transport can be 


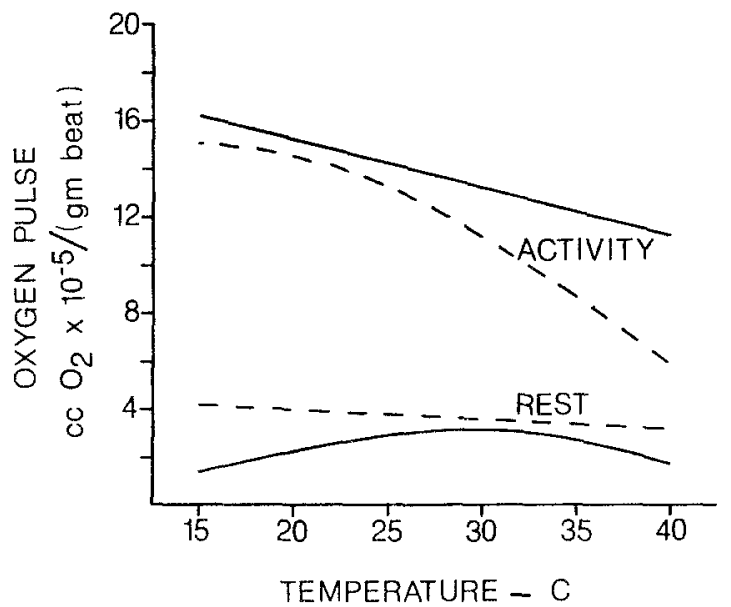

Fig. 9. Oxygen pulse during rest and maximal activity in Sauromalus hispidus (dashed lines) and Varanus gouldii (solid lines)

Table 3. Percentage contribution of increased heart rate to increased oxygen transport during activity in Sauromalus hispidus and Varanus gouldii. Calculations are based on Eq. (10)

\begin{tabular}{lll}
\hline $\begin{array}{l}\text { Body } \\
\text { temperature } \\
\left({ }^{\circ} \mathrm{C}\right)\end{array}$ & \multicolumn{2}{c}{ Percentage contribution } \\
\cline { 2 - 3 } & Sauromalus & Varanus \\
\hline 15 & 55 & 10 \\
20 & 51 & 15 \\
25 & 49 & 20 \\
30 & 51 & 19 \\
35 & 56 & 15 \\
37.5 & 60 & 12 \\
40 & 65 & 10 \\
\hline
\end{tabular}

calculated according to the formula given by Bartholomew and Tucker (1963), modified from the Fick principle:

$$
\% \text { contribution }=\frac{A H R-S H R}{S H R} \div\left(\frac{A H R-S H R}{S H R}+\frac{A O P-S O P}{S O P}\right)
$$

in which AHR, SHR, AOP, and SOP are active and standard heart rates and oxygen pulses, respectively. The percentage contribution of heart rate to increased oxygen transport during activity is calculated for Sauromalus and Varanus in Table 3 . It is clear that the former relies 
much more heavily on heart rate increment to supply oxygen durin activity than does the latter.

\section{Discussion \\ Oxygen Consumption and Scope}

The standard metabolic rates of both species at their preferred $T_{b}$, $37.5^{\circ} \mathrm{C}$, are nearly equal: Sauromalus, $0.088 \mathrm{cc} \mathrm{O}_{2} /(\mathrm{g} \times \mathrm{hr}) ;$ Varanus, $0.111 \mathrm{cc} \mathrm{O}_{2} /(\mathrm{g} \times \mathrm{hr})$. The varanid, however, consumes nearly twice the amount of oxygen during peak activity as does the iguanid. These experiments confirm the conclusions of Bartholomew and Tucker (1964) that Varanus possess an aerobic scope superior to comparably-sized reptiles. A separate series of experiments determined that the low aerobic scope of Sauromalus is accompanied by extensive production of lactic acid during activity. Varanus experiences only moderate anaerobiosis under identical experimental conditions (Bennett, 1971). The total work performed during stimulation was not measured and may not be equal in the two species. It is the pattern of maximal activity, however, which is of interest: low aerobic scope, high lactate production and exhaustion in Sauromalus; high scope and moderate anaerobiosis in Varanus.

The metabolic capacities reported here may be compared to those reported for other reptiles. According to the relation calculated by Templeton (1970) for metabolic rate of lizards at $37^{\circ} \mathrm{C}$, Sauromalus hispidus has a metabolic rate $60 \%$ and Varanus gouldii, $80 \%$ of expected metabolic rate on the basis of body size. These lower rates are probably due more to circadian differences than to genuinely depressed metabolism; most of Templeton's data are: based on diurnal observations. Metabolic rates of 0.087 and $0.312 \mathrm{cc} \mathrm{O}_{2} /(\mathrm{g} \times \mathrm{hr})$ have been reported for Sauromalus obesus at $35^{\circ} \mathrm{C}$ (Boyer, 1967; Crawford and Kampe, 1971). The plateau in active oxygen consumption in Sauromalus hispidus is virtually identical to that reported for Iguana iguana (Moberly, 1968a), the only other large iguanid for which scope has been examined. Metabolic rates are reported for several species of varanids, including Varanus gouldii, by Bartholomew and Tucker (1964). Their data were gathered only at $20^{\circ}, 30^{\circ}$, and $40^{\circ} \mathrm{C}$, and consequently do not include the plateau of metabolic rate between $30^{\circ}$ and $40^{\circ} \mathrm{C}$. Their animals began hyperventilating at $38^{\circ} \mathrm{C}$, and although they state that gular pumping did not usually occur during the quiet periods at $40^{\circ} \mathrm{C}$, their data are identical to those for resting animals at $20^{\circ}$ and $30^{\circ} \mathrm{C}$ and hyperventilating animals at $40^{\circ} \mathrm{C}$ in this study. Their conclusion that the standard metabolic rate of Varanus at $38^{\circ} \mathrm{C}$ is one-third that of a comparably- 
sized homeotherm is, therefore, an overestimation: at rest, the energy expenditure of this lizard is no greater than that of other saurians. Data gathered in these experiments indicate that the standard metabolic rate of Varanus is one-sixth that of a mammal of the same size, according to the relationship proposed by Kleiber (1961). The metabolic rates of active Varanus reported by Bartholomew and Tucker are lower than those presented here, but the temperature dependence is the same.

The independence of metabolic rate with increasing $T_{b}$ near the activity range, as reported for Varanus, is not unusual in reptiles (see, for instance, Cook, 1949; Dawson and Templeton, 1963; Mayhew, 1965) although the most common pattern is that of constant $Q_{10}$ as observed for Sauromalus hispidus. The possession of a temperature-independent metabolic pattern would free an organism from fluctuations in energy expenditure with minor changes in $T_{b}$ and "perhaps ... indicates a tendaney towards homeostasis in these species" (Dawson and Bartholomew, 1956).

The $2.0^{\circ} \mathrm{C}$ increment in $T_{b}$ during activity reported for Varanus (Bartholomew and Tucker, 1964) is not exceptional for a large reptile (see Benedict, 1932) and is not indicative of special metabolic capacities. Body temperature of Sauromalus increased more in these experiments than did that of Varanus. This increment is highly dependent upon experimental conditions: the insulating quality of the metabolic chamber and temperature cabinet, the rate of air movement, etc.

A declining aerobic scope with increasing $T_{b}$ may be the result of a rapidly increasing standard metabolic rate or a constant or declining active metabolic rate. For all reptiles examined except Varanus and Tiliqua scincoides (Bartholomew et al., 1965), the active metabolic rate has a low $Q_{10}$ value at higher $T_{b}$. Scope in the latter animal is low. Declining scope, therefore, appears to be a result of a limitation of oxygen consumption during activity in reptiles. Brett (1964) found a similar situation in sockeye salmon, which he interpreted as an oxygen limitation in the fluid medium. When the oxygen content of the water was artifically increased, oxygen consumption during activity increased, revealing a constant $Q_{10}$ relationship between active metabolism and $T_{b}$. Oxygen limitation appears to be an unlikely hypothesis for airbreathing organisms, since the relative concentration is much higher than in water. However, many physiological systems are involved in procuring and transporting oxygen before it reaches the site of utilization within the cells. It is possible that one or more of these systems is saturated at a relatively low $T_{b}$ in most reptiles and is unable to increase oxygen delivery or utilization with further increments in $T_{b}$. Additional energy would have to be derived from anaerobic sources. 


\section{Recovery}

At $40^{\circ} \mathrm{C}$, Varanus recovers from activity more than three times as rapidly as Sauromalus. Its total oxygen debt is only two-thirds that of the iguanid, presumably because of the smaller lactacid component of the debt. If the fast and slow recovery components do represent alactacid and lactacid debts, respectively, an interesting pattern of aerobiosis and anaerobiosis emerges for both species. The constancy of the alactacid debt of Sauromalus at all $T_{b}$, comparable to the highest debt observed in Varanus, suggests that the iguanid exhausts its non-glycolytic energy reserves during activity and relies heavily on anaerobic metabolism. Varanus, however, undergoes moderate anaerobiosis at all $T_{b}$ 's and depletes its non-glycolytic energy sources only at higher $T_{b}$. Moderate lactate buildup is common in man even at low levels of activity (DeLanne et al., 1959; Karpovich, 1959). The validity of the recovery model has not been tested for reptiles. Satisfactory testing would involve the estimation of the total non-glycolytic energy reserves of an animal and measurement of total lactate produced during activity and the time course of its elimination. Blood lactate content after activity is highly temperature dependent in Sauromalus but is independent of $T_{b}$ in Varanus (Bennett, 1971). This observation is in accord with the thermal dependence of the slow (lactacid) recovery component of oxygen consumption in both animals.

It is rather surprising that no other studies of oxygen debt or recovery time have been made in reptiles, since these variables are easily measured. The effects of $T_{b}$, length of activity, and body size on oxygen debt would all be of interest in view of the anaerobiosis undergone by some animals. Moberly (1968a) monitored the concentration of blood lactate after activity in Iguana. Lactate is removed most rapidly at $35^{\circ} \mathrm{C}$ and the rate of removal at $40^{\circ} \mathrm{C}$ is intermediate to that at $25^{\circ}$ and $30^{\circ} \mathrm{C}$. This condition is paralleled by the recovery rates of the lactacid component of oxygen debt for Sauromalus. The time constants for lactate elimination are nearly twice those predicted on the basis of oxygen consumption in Sauromalus: $30^{\circ} \mathrm{C}, 64 \mathrm{~min} ; 40^{\circ} \mathrm{C}, 73 \mathrm{~min}$.

\section{Heart Rate}

An inability to increase heart rate to meet oxygen demands during activity is obviously not the causal factor of the low aerobic scope of Sauromalus. In fact, increased heart rate is the principle means of adjusting cardiac output during activity. In Varanus, as Bartholomew and Tucker (1964) suggest, changes in stroke volume and arterial-venous difference (A-V difference) are more important than changes in heart rate in supplying oxygen to active tissues. The large heart rate increment 
of the iguanid is the result of a very low standard heart rate, since the active heart rates of the two animals are nearly identical. Resting heart rate in Sauromalus hispidus is only three-fifths the average rate reported. for other large lizards (Amblyrhynchus, Bartholomew and Lasiewski, 1965; Iguana, Tucker, 1966, Moberly, 1968a; Tiliqua, Bartholomew et al., 1965, Licht, 1965; Varanus, Bartholomew and Tucker, 1964). Whether particularly low standard heart rates are characteristic of the genus Sauromalus is unclear: the heart rate of S.obesus is reported as 95 beats/min (Templeton, 1964) and 58 beats/min (Boyer, 1967) at $37^{\circ} \mathrm{C}$. Resting heart rates reported for several species of Varanus (Bartholomew and Tucker, 1964) are three-fourths those determined for V. gouldii; active heart rates also differ by this factor.

\section{Oxygen Pulse}

According to the Fick principle, the amount of oxygen consumed by an organism must be equal to the product of the blood flow (the product of heart rate and stroke volume) and the difference in the oxygen content of the blood entering and leaving the metabolizing tissue (A-V difference). Organismal oxygen consumption and heart rate are readily accessible factors, the A-V difference is less so, and the stroke volume is almost always estimated by measurement of the other factors. The oxygen pulse, the amount of oxygen transported per heart beat, can easily be calculated from metabolic and heart rates. Through the Fick equivalence, oxygen pulse is equal to the product of stroke volume and $\mathrm{A} \cdot \mathrm{V}$ difference; consequently, it is a valuable calculation for examining changes in these variables. An increase in oxygen pulse, as observed during activity, is the result of an equal increase in the product of stroke volume and A-V difference. Likewise, a declining oxygen pulse, as observed in both animals, particularly in Sauromalus, during activity with increasing $T_{b}$, must reflect a fall in stroke volume and/or a decrease in $\mathrm{A}-\mathrm{V}$ difference. The latter might occur by a rise in the oxygen concentration of venous blood or a decrease in the saturation of arterial blood, a failure to load adequate quantities of oxygen in the lung.

The constancy of standard values of oxygen pulse between lizard species is impressive. The values generally approximate $3 \times 10^{-5}$ to $4 \times 10^{-5}$ ce $\mathrm{O}_{2} /(\mathrm{g} \times$ beat) (Dawson, 1967 ; Templeton, 1970$)$; the values for Varanus and Sauromalus conform to this range. Oxygen pulse values for active reptiles are given in Table 4 . The oxygen pulse during activity exceeds $10 \times 10^{-5} \mathrm{cc} \mathrm{O}_{2} /(\mathrm{g} \times$ beat $)$ in all but the most sluggish animals. Increased $T_{b}$ decreases this quantity in all species except Varanus. This pulse value of Varanus is exceptionally high and reflects and ability to increase stroke volume or A-V difference during activity which greatly exceeds other reptiles investigated. 
Table 4. Oxygen pulse in active reptiles

\begin{tabular}{|c|c|c|c|c|c|}
\hline \multirow[t]{2}{*}{ Species } & \multicolumn{2}{|c|}{ Maximum $\mathrm{O}_{2}$ pulse } & \multicolumn{2}{|c|}{ Pulse at high $T_{b}$} & \multirow[t]{2}{*}{ Reference } \\
\hline & $\begin{array}{l}T_{b} \\
\left({ }^{\circ} \mathrm{C}\right)\end{array}$ & $\begin{array}{l}\text { cc } \mathrm{O}_{2} \times 10^{-5} / \\
(\mathrm{gm} \times \text { beat })\end{array}$ & $\begin{array}{l}T_{b} \\
\left({ }^{\circ} \mathrm{C}\right)\end{array}$ & $\begin{array}{l}\mathrm{cc}_{2} \times 10^{-5} / \\
(\mathrm{gm} \times \text { beat })\end{array}$ & \\
\hline $\begin{array}{l}\text { Amphibolurus } \\
\text { barbatus }\end{array}$ & 20 & 12.2 & 40 & 3.7 & $\begin{array}{l}\text { Bartholomew and } \\
\text { Tucker (1963) }\end{array}$ \\
\hline Iguana iguana & 30 & 10.4 & 40 & 6.1 & Moberly (1968a) \\
\hline $\begin{array}{l}\text { Pituophis } \\
\text { catenifer }\end{array}$ & 20 & 10.2 & 35 & 7.5 & Greenwald (1971) \\
\hline $\begin{array}{l}\text { Sauromalus } \\
\text { hispidus }\end{array}$ & 15 & 15.0 & 40 & 6.3 & Present study \\
\hline $\begin{array}{l}\text { Sphenodon } \\
\quad \text { punctatus }\end{array}$ & 5 & 9.2 & 35 & 2.0 & $\begin{array}{l}\text { Wilson and Lee } \\
(1970)\end{array}$ \\
\hline Titiqua scincoides & 20 & 6.3 & 40 & 5.4 & $\begin{array}{l}\text { Bartholomew } \\
\text { et al. (1965) }\end{array}$ \\
\hline Varanus spp. & 40 & 10.7 & 40 & 10.7 & $\begin{array}{l}\text { Bartholomew and } \\
\text { Tucker (1964) }\end{array}$ \\
\hline Varanus gouldii & 15 & 16.5 & 40 & 11.3 & Present study \\
\hline
\end{tabular}

Determinations of A-V difference or stroke volume in reptiles are few (Templeton, 1964; Tucker, 1966). From the information available, it appears that stroke volume is not greatly modified during activity or change in $T_{b}$, so that oxygen pulse must principally reflect adjustment of the $A-V$ difference in reptiles. The rapid decline in active oxygen pulse of Sauromalus between $30^{\circ}$ and $40^{\circ} \mathrm{C}$ is probably due to a decrease in the saturation of arterial blood, since it is highly doubtful that the oxygen content of the venous blood is increasing with increased metabolic demands.

\section{Conclusions}

Varanus gouldii is shown in this study to possess a standard metabolic rate equal to that of comparably-sized lizards. However, its capacities for transporting oxygen during activity are high and maximal oxygen consumption exceeds resting levels of homeotherms of equal size. Consequently, oxygen debt acquired during activity is low and is rapidly repayed. The high active oxygen pulse indicates a great capacity for increasing either stroke volume or A-V difference during activity.

Sauromalus hispidus conforms closely to the metabolic pattern established for Iguana iguana (Moberly, 1968a, b), an animal which relies heavily on anaerobiosis during activity and exhausts easily. Active oxygen consumption in Sauromalus does not increase with increasing $T_{b}$ above $30^{\circ} \mathrm{C}$, and, therefore, aerobic scope remains low. Oxygen debt 
is high, presumably because of its large lactacid component, and recovery of standard metabolic levels is slow. A low heart rate increment is not responsible for this limitation of oxygen uptake during activity. Calculations of oxygen pulse suggest that $\mathrm{A}-\mathrm{V}$ difference cannot be greatly increased to meet oxygen demands during activity due to low saturation of arterial blood.

From the evidence available, iguanid lizards appear to have a high tolerance of anaerobiosis. Iguanids survive twice as long as other lizards in an atmosphere of pure nitrogen (Belkin, 1963). Sauromalus and Dipsosaurus have high levels of muscle phosphofructokinase activity (Bennett, 1972); this enzyme controls the rate-limiting reaction in glycolysis and a high activity indicates a large anaerobic capacity. Moberly (1968b) emphasized anaerobiosis in Iguana iguana as an adaptation to diving and found it rather remarkable in an arboreal animal which dives only infrequently. It appears, however, that a considerable reliance on anaerobiosis may be primatively characteristic of the Iguanidae and that several of its members (Iguana, Amblyrhynchus, Basiliscus, and Anolis) have exploited this tolerance of anoxia for escape or feeding purposes.

It should be emphasized that the metabolic physiology of each of these lizards is highly adapted to its behavior and mode of existence. Sauromalus, an herbivore, engages in maximal activity only rarely, e.g., when pursued (an unlikely occurrence in its natural habitat) or perhaps during mating or territorial defense. Short bursts of anaerobically generated energy are quite adequate for such circumstances, and it is difficult to imagine the selective advantage of increased aerobic dependence. On the other hand, a varanid generally has a very large home range, is extensively active, and often pursues its prey. A large lactate buildup, with its disruptive physiological effects and consequent long recovery period, would be distinctly disadvantageous to such an animal. It appears that Varanus has evolved mechanisms to sustain high levels of oxygen delivery to its tissues even during the most strenuous activity.

This paper is a portion of a doctoral thesis submitted to the Department of Zoology at the University of Michigan. I thank Profs. Horace Waring and Albert R. Main of the University of Western Australia for the opportunity to work at that institution as a visiting investigator. In particular, I wish to thank Prof. W. R. Dawson for his assistance and advice throughout my graduate tenure. Prof. Stephen P. Hubbell was most helpful with the mathematical analysis of the data. Financial support for this study was provided by four Graduate Fellowships (1966-1970) from the National Science Foundation, NSF Grant GB-3656 to Prof. W. R. Dawson, the Graduate Student Research Fund of the Horace H. Rackham School of Graduate Studies, and NSF Grant GB-8212 to Prof. N. G. Hairston for research in Systematic and Evolutionary Biology. Thanks are extended to Prof. Paul Licht for critically reading the manuscript. 


\section{References}

Atkins, G. L.: Multicompartment models for biological systems. London: Methuen and Co., Ltd. 1969.

Bartholomew, G. A., Lasiewski, R. C.: Heating and cooling rates, heart rate and simulated diving in the Galapagos marine iguana. Comp. Biochem. Physiol. 16, 573-582 (1965).

Bartholomew, G. A., Tucker, V. A.: Control of changes in body temperature, metabolism, and circulation by the agamid lizard, Amphibolurus barbatus. Physiol. Zool. 36, 199-218 (1963).

Bartholomew, G. A., Tucker, V. A.: Size, body temperature, thermal conductance, oxygen consumption, and heart rate in Australian varanid lizards. Physiol. Zool. 37, 341-354 (1964).

Bartholomew, G. A., Tucker, V.A., Lee, A.K.: Oxygen consumption, thermal conductance, and heart rate in the Australian skink Tiliqua scincoides. Copeia 1965, 169-173 (1965).

Belkin, D. A. : Anoxia: Tolerance in reptiles. Science 139, 492-493 (1963).

Benedict, F. G.: The physiology of large reptiles. Washington, D. C.: Carnegie Inst. Washington Publ. 425, 1932.

Bennett, A. F.: Oxygen transport and energy metabolism in two species of lizards, Sauromalus hispidus and Varanus gouldii. Ph. D. Thesis, Univ. of Michigan, Ann Arbor, 1971.

Bennett, A. F.: A comparison of activities of metabolic enzymes in lizards and rats. Comp. Biochem. Physiol, in press (1972).

Bennett, A. F., Dawson, W. R.: Oxygen consumption: reptiles. Table 175:III, p. 472-481. In: Respiration and circulation, ed. P. L. Altman and D. S. Dittmer. Bethesda, Maryland: Fed. Amer. Soc. Exper. Biol. 1971.

Boyer, D. R.: Interaction of temperature and hypoxia on respiratory and cardiac responses in the lizard, Sauromalus obesus. Comp. Biochem. Physiol. 20, 437-447 (1967).

Brattstrom, B. H.: Body temperature of reptiles. Amer. Midl. Nat. 73, 376-422 (1965).

Brett, J. R.: The respiratory metabolism and swimming performance of young sockeye salmon. J. Fish. Res. Bd. Canada 21, 1183-1226 (1964).

Cook, S. F.: Respiratory metabolism of certain reptiles and amphibia. Univ. Calif. Pub. Zool. 53, 367-376 (1949).

Copland, S.: Blood vascular system of the trunk of the goanna Varanus varius (Shaw). Proc. Lin. Soc. New South Wales 78, iii-xviii (1953).

Cowles, R. B.: The life history of Varanus niloticus (Linnaeus) as observed in Natal South Africa. J. entomol. Zool. 22, 3-31 (1930).

Crawford, E. C., Jr., Kampe, G.: Physiological responses of the lizard Sauromalus obesus to changes in ambient temperature. Amer. J. Physiol. 220, 1256-1260 (1971).

Dawson, W. R.: Interspecific variation in physiological responses of lizards to temperature, p. 230-257. In: Lizard ecology, ed. W. W. Milstead. Columbia: Univ. of Missouri Press 1967.

Dawson, W. R., Bartholomew, G. A.: Relation of oxygen consumption to body weight, temperature, and temperature acclimation in lizards Uta stansburiana and Sceloporus occidentalis. Physiol. Zool. 29, 40-51 (1956). 
Dawson, W. R., Templeton, J. R.: Physiological responses to temperature in the lizard Crotaphytus collaris. Physiol. Zool. 36, 219-236 (1963).

DeLanne, R., Barnes, J. R., Brouha, L., Massart, F.: Changes in acid-base balance and blood gases during muscular activity and recovery. J. appl. Physiol. 14, 328-332 (1959).

Fry, F. E. J.: Effects of the environment on animal activity. Pub. Ont. Fish. Res. Lab. No. 68, 1-62 (1947).

Greenwald, O. E. : The effect of body temperature on oxygen consumption and heart rate in the Sonora gopher snake, Pituophis cateniter affinis Hallowell. Copeia 1971, 98-106 (1971).

Henry, F. M.: Aerobic oxygen consumption and alactic debt in muscular work. J. appl. Physiol. 3, 427-438 (1951).

Henry, F. M., DeMoor, J. C.: Lactic and alactic oxygen consumption in moderate exercise of graded intensity. J. appl. Physiol. 8, 608-614 (1956).

Karpovich, P. V.: Physiology of muscular activity, 5th ed. Philadelphia: W. B. Saunders Co. 1959.

Kirschfeld, U.: Eine Bauplananalyse der Waranlunge. Zool. Beitr., N. F. 16, 401440 (1970).

Kleiber, M.: The fire of life, 2nd ed. New York: John Wiley and Sons, Inc. 1961.

Licht, P.: Effects of temperature on heart rates of lizards during rest and activity. Physiol. Zool. 38, 129-137 (1965).

Licht, P., Dawson, W. R., Shoemaker, V. H., Main, A. R.: Observations on the thermal relations of Western Australian lizards. Copeia 1966, 97-110 (1966).

Mathur, P. N.: The anatomy of the reptilian heart. Part I. Varanus monitor (Linné). Proc. Ind. Acad. Sci., Sect. B 20, 1-29 (1944).

Mayhew, W. W.: Hibernation in the horned lizard, Phrynosoma m'calli. Comp. Biochem. Physiol. 16, 103-119 (1965).

Mertens, R.: Die Familie der Warane (Varanidae). I. Allgemeines. Abh. Senckenberg. naturforsch. Ges. 462, 1-116 (1942).

Milani, A.: Beiträge zur Kenntnis der Reptilienlunge. I. Lacertilia. Zool. Jb. 7, $545-592$ (1894).

Moberly, W. R.: The metabolic responses of the common iguana, Iguana iguana, to activity under restraint. Comp. Biochem. Physiol. 27, 1-20 (1968a).

Moberly, W. R.: The metabolic responses of the common iguana, Iguana iguana, to walking and diving. Comp. Biochem. Physiol. 27, 21-32 (1968b).

Norris, K. S., Dawson, W. R.: Observations on the water economy and electrolyte excretion of chuckwallas (Lacertilia, Sauromalus). Copeia 1964, 638-646 (1964).

Pianka, E. R.: Notes on the biology of Varanus gouldii flavirufus. West. Aust. Nat. 11, 141-144 (1970).

Roberts, L. A.: Oxygen consumption in the lizard Uta stansburiana. Ecology 49, 809-819 (1968).

Romer, A. S.: Osteology of the reptiles. Chicago: Univ. of Chicago Press 1956.

Templeton, J. R.: Cardiovascular response to temperature in the lizard Sauromalus obesus. Physiol. Zool. 37, 300-306 (1964).

Templeton, J. R.: Reptiles, p. 167-221. In: Comparative physiology of thermoregulation, vol. 1, Invertebrates and nonmammalian vertebrates, ed. G. C. Whittow. New York: Academic Press 1970. 
Tucker, V. A.: Oxygen transport by the circulatory system of the green iguana (Iguana iguana) at different body temperatures. J. exp. Biol. 44, 77-92 (1966).

Tucker, V. A.: The role of the cardiovascular system in oxygen transport and thermoregulation in lizards, p. 258-269. In : Lizard ecology, ed. W. W. Milstead. Columbia : Univ. of Missouri Press 1967.

Wilson, K. J., Lee, A. K.: Changes in oxygen consumption and heart-rate with activity and body temperature in the tuatara, Sphenodon punctatum. Comp. Biochem. Physiol. 33, 311-322 (1970).

Wolf, S.: Zur Kenntnis von Bau und Funktion der Reptilienlunge. Zool. Jb. 57, $139-190$ (1933).

Dr. Albert F. Bennett

Department of Zoology

University of Michigan

Ann Arbor, Michigan 48104, U.S.A.
Present address :

Department of Zoology

University of California

Berkeley, California 94720, U.S.A. 